\title{
Taxonomy of the Genus Cellulomonas, Based on Phenotypic Characters and Deoxyribonucleic Acid-Deoxyribonucleic Acid Homology, and Proposal of Seven Neotype Strains
}

\author{
ERKO STACKEBRANDT $†$ AND OTTO KANDLER ${ }^{\prime}$
}

\begin{abstract}
Deutsche Sammlung von Mikroorganismen der Gesellschaft für Strahlen und Umweltforschung mbH, Teilsammlung München, and Botanisches Institut der Universität München, D-8000 München 19, ${ }^{1}$ Bundesrepublik Deutschland
\end{abstract}

\begin{abstract}
Proposed as neotype strains of their respective species are the following: Cellulomonas biazotea ATCC 486, C. cellasea ATCC 487, C. fimi ATCC 484, C. flavigena ATCC 482, C. gelida ATCC 488, C. subalbus ATCC 489, and C. uda ATCC 491. Deoxyribonucleic acid-deoxyribonucleic acid reassociation studies on these and three other reference strains of Cellulomonas clearly revealed seven distinct species: C. biazotea, C. flavigena, C. cellasea, C. fimi, C. gelida, C. uda, and $C$. cartalyticum. C. subalbus ATCC 489 is identical with $C$. gelida ATCC 488 on the basis of genetic evidence. These results are confirmed by physiological data. $C$. subalbus is therefore a junior synonym of $C$. gelida. The polysaccharide and amino acid composition of the cell wall, the electrophoretic mobility of the L-lactate dehydrogenase, and the utilization of certain sugars and organic acids were found to be useful characters in species differentiation. Although the deoxyribonucleic acid-deoxyribonucleic acid homology values within the genus Cellulomonas range between 20 and 100\%, those between strains of Cellulomonas and strains of Arthrobacter, Corynebacterium, and Brevibacterium are lower than $8 \%$. These data, supported by the high guanine plus cytosine content of the DNA, the ability to decompose cellulose, and the similarity in the peptidoglycan types, demonstrate the coherence of the members of the genus Cellulomonas and the validity of the inclusion of this genus in the family Corynebacteriaceae.
\end{abstract}

According to the description of Cellulomonas Bergey et al. (1) given by Clark $(7,8)$ over 25 years ago, this genus includes only aerobic, nonsporeforming, cellulose-utilizing bacteria which produce acid from glucose. Since that time, several studies have been carried out to characterize these organisms in greater detail. Except for the more recent investigations of Seiler et al. (33) and Jones (19), the numerical taxonomy studies on these organisms (e.g., Da Silva and Holt [11], Davis and Newton [12], Stuart and Pease [37], and Bousfield [3]) were restricted to a very limited number of strains and led to contradictory results. Some of the strains investigated by these authors were placed in other genera of the family Corynebacteriaceae even though they were strongly cellulolytic.

In the present study, most of the currently available strains of Cellulomonas were characterized according to the type of peptidoglycan of their cell wall (14), the guanine plus cytosine $(\mathrm{G}+\mathrm{C})$ content of their deoxyribonucleic acid (DNA) (41), the fermentation pattern (34), and

† Present address: Technische Universität München, Lehrstuhl für Mikrobiologie, D-8000, München 2, Bundesrepublik, Deutschland. the serological properties (4). With respect to these characters, a relatively high degree of uniformity was noted with these strains. However, differences between the named species could clearly be demonstrated despite the fact that only one species was recognized in the last edition of Bergey's Manual (19), namely, Cellulomonas flavigena. In this paper the phenotypic characters of 10 reference strains, including seven proposed neotype strains, assigned to eight different named species are compared with the DNA-DNA homology data from these strains. The evidence indicates that the recognition of at least seven species in the genus Cellulomonas is justified.

\section{MATERIALS AND METHODS}

Bacterial strains. The following strains employed in this investigation were obtained from Deutsche Sammlung von Mikroorganismen (DSM): Cellulomonas biazotea DSM 20112 (= American Type Culture Collection [ATCC] 486), C. cartalyticum DSM 20106 (= ATCC 21681), C. cellasea DSM 20118 (= National Collection of Industrial Bacteria [NCIB] 8078), C. fimi DSM 20113 (= ATCC 484), C. fimi DSM 20114 (= ATCC 15724), C. flavigena DSM 20109 (= ATCC 482), C. gelida DSM 20111 (= ATCC 488), 
Cellulomonas sp. DSM 20108 (= ATCC 21399), C. subalbus DSM 20110 (= NCIB 8075), C. uda DSM 20107 (= ATCC 491), Arthrobacter atrocyaneus DSM 20127 (= ATCC 13752), A. aurescens DSM 20116 (= ATCC 13344), A. globiformis DSM 20124 (= ATCC 8010), $A$. oxidans DSM 20119 (= ATCC 14358), $A$. ureafaciens DSM 20126 (= ATCC 7562), A. variabilis DSM 20132 (= ATCC 15753), A. viscosus DSM 20159 (= ATCC 15294), Brevibacterium linens DSM 20158 (= ATCC 19391), and Corynebacterium glutamicum DSM 20300 (= ATCC 13032). Cellulomonas sp. strain DS was obtained from Cellulomonas sp. D.S. Vaughn, Univeisity of California, Davis.

Media and growth conditions. Stock cultures were routinely maintained on yeast-glucose agar slants (peptone, 1\%; yeast extract, $0.5 \%$; glucose, $0.5 \%$; agar (Difco), $1 \%, \mathrm{pH} 7.3$ ) stored at $4^{\circ} \mathrm{C}$. All physiological tests were carried out aerobically at $30^{\circ} \mathrm{C}$ in this medium prepared without agar. The basal medium for the utilization of carbohydrates and organic acids contained no glucose. Filter-sterilized solutions of test substrates were added to a final concentration of $0.5 \%$. For mass cultures, a semisynthetic medium prepared as described by Morris (30) was used. Some slowgrowing strains were found to grow more rapidly when Merck multivitamin solution $(0.2 \mathrm{ml} / \mathrm{liter})$ was added to the medium.

For the isolation of unlabeled and labeled DNA, the organisms were grown in 2 liters of medium in 5-liter Erlenmeyer flasks and in $300 \mathrm{ml}$ of medium in 1-liter Erlenmeyer flasks, respectively.

Physiological tests. Carbohydrate utilization was tested by descending paper chromatography. Samples of growing cultures, taken every other day for 14 days, were centrifuged, and $5 \mu \mathrm{l}$ of the supernatant was applied to Whatman no. 1 paper. A 5- $\mu$ l portion of uninoculated medium served as a control. Samples were chromatographed in a mixture of butanol-pyridine-glacial acetic acid-water $(60: 40: 30: 3)$ for $12 \mathrm{~h}$. After drying, chromatograms were developed with Trevelyan reagent (39). A reduction or disappearance of the carbohydrate spot indicated a partial or complete oxidation of the carbohydrate. Acetic acid was determined enzymatically by the method of Holz and Bergmeyer (18), and L-lactic acid was determined by the procedure of Hohorst (15). Ammonia production from peptone was tested for in a broth containing no glucose. After 3 and 8 days of incubation, $0.1 \mathrm{ml}$ of Nessler reagent (Merck) was added to $0.2 \mathrm{ml}$ of the culture; a yellow or orange color was scored as a positive result. Nitrate reduction was determined in a medium containing $0.2 \% \mathrm{KNO}_{3}$. Every other day, $0.3-$ $\mathrm{ml}$ samples were tested with Gries Ilosvaye reagent (Merck) by the method described by Cowan and Steel (9) for the presence of nitrite. After 14 days, negative tests were confirmed by adding zinc dust to reduce the residual nitrate to nitrite and by then observing a positive reaction for nitrite. The electrophoretic mobility of L-lactate dehydrogenase (EC 1.1.1.27) was determined by the method of Maurer (27) modified by using glycyl-glycine buffer (31), pH 7.4. Protein was detected by staining by the procedure of Weber and Osborn (40). Rabbit muscle L-lactic dehydrogenase isoenzyme I (Boehringer, Mannheim, West Germany) served as a reference.
DNA hybridization (i) Preparation of the DNA. Cells were harvested from the late log phase, washed twice in saline ethylenediaminetetraacetic acid (EDTA) buffer (0.15 M NaCl, 0.1 M EDTA, pH 8.0), and lysed by incubation at $37^{\circ} \mathrm{C}$ for $30 \mathrm{~min}$ in the same buffer ( $15 \mathrm{ml} / \mathrm{g}$ of cells) containing $0.05 \%$ lysozyme. Total lysis was achieved by adding $2 \%$ (wt/vol) sodium dodecyl sulfate. Extraction and purification of DNA were carried out as described by Marmur (25) with slight modifications: the crude extract was made $1 \mathrm{M}$ with respect to $\mathrm{NaCl}$, an equal volume of chloroformisoamyl alcohol (24:1) was added, and the solution was shaken vigorously for $20 \mathrm{~min}$. After centrifugation (20 min at $12,000 \times g$ ), the clear upper phase was made up to $1 \% N, N$,-cethyltrimethylammoniumbromide (CTAB) by the method of Darby (10). Upon dilution with distilled water ( 0.1 volume), the CTAB salts of the nucleic acids were precipitated and then collected by centrifugation $(20 \mathrm{~min}$ at $12,000 \times \mathrm{g})$. The pellet was dissolved in $1 \mathrm{M} \mathrm{NaCl}$, and the CTAB was removed by shaking with an equal volume of chloroform. After precipitating the DNA with isopropanol $(0.56$ volume) and dissolving it in $0.1 \times \mathrm{SSC}(0.015 \mathrm{M} \mathrm{NaCl}$, $0.015 \mathrm{M}$ trisodium citrate), the solution was made up to $1 \times$ SSC. Ribonucleic acid was digested for $12 \mathrm{~h}$ at $37^{\circ} \mathrm{C}$ by the addition of $50 \mu \mathrm{g}$ of ribonuclease per $\mathrm{ml}$. To remove protein which resisted the earlier CTAB step and the chloroform deproteinization, the solution was treated with a proteinase $\mathrm{K}(50 \mu \mathrm{g} / \mathrm{ml})$ for. $12 \mathrm{~h}$. The proteinase was removed by shaking the solution twice with equal volumes of chloroform. After a final precipitation with isopropanol, the DNA was dissolved and then dialyzed against SSC-EDTA buffer $(0.15 \mathrm{M}$ $\mathrm{NaCl}, 0.015 \mathrm{M}$ trisodium citrate, $0.2 \mathrm{M}$ EDTA, $\mathrm{pH}$ 7.0) for $48 \mathrm{~h}$.

Labeled DNA was extracted from cells which were cultivated in a medium containing $1 \mathrm{mCi}$ of $\left[{ }^{3} \mathrm{H}\right]$ thymidine per $300 \mathrm{ml}$ of broth. Cells were harvested at the end of the log phase. After disruption of the cells with glass beads in a cell mill (Buehler), the purification of DNA was performed as described above. The specific radioactivity of ${ }^{3} \mathrm{H}$-labeled DNA thus obtained ranged between $2 \times 10^{3}$ and $18 \times 10^{3} \mathrm{cpm} / \mu \mathrm{g}$ of DNA.

The amount of DNA was determined by the method of Burton (6), in which calf thymus DNA was used as a standard. The purified DNA was stored in the cold in the presence of several drops of chloroform.

(ii) Preparation of DNA filter. Denatured DNA was prepared by the method of Bernstiel et al. (2). A 1-ml amount of DNA solution containing $150 \mu \mathrm{g}$ of DNA in $1 \times$ SSC was denatured by adding $1 \mathrm{ml}$ of $1 \mathrm{~N}$ $\mathrm{NaOH}$ solution and allowing it to stand for $20 \mathrm{~min}$ at room temperature. The $\mathrm{pH}$ was then neutralized with $8 \mathrm{ml}$ of a buffer solution $(1 \mathrm{~N} \mathrm{NaCl}, 1 \mathrm{~N} \mathrm{HCl}, 1 \mathrm{M}$ tris(hydroxymethyl)aminomethane $=2: 1: 1$ ). The denatured DNA solution was passed at moderate speed $(1 \mathrm{ml} / 3 \mathrm{~min})$ at low temperature $\left(3^{\circ} \mathrm{C}\right)$ through a nitrocellulose membrane filter (25-mm diameter, 0.2 $\mu \mathrm{m}$ pore diameter, Schleicher and Schüll) that had been presoaked in $3 \times$ SSC for $30 \mathrm{~min}$. DNA filters were washed three times with cold $3 \times$ SSC. The binding efficiency of the DNA to nitrocellulose filters ranged between $88 \%$ and $95 \%$ of the input DNA. Eighty percent of the DNA was retained by the filter during incubation of the DNA filter under hybridiza- 
tion conditions. Binding efficiency was determined by comparing the absorbance at $260 \mathrm{~nm}$ of the DNA solution before and after passage through the filter.

Filters were air dried overnight at room temperature and then placed in a vacuum oven for $4 \mathrm{~h}$ at $80^{\circ} \mathrm{C}$. The filters were stored at $4^{\circ} \mathrm{C}$ in a desiccator containing calcium chloride. For the experiments, eight small filters (5-mm diameter), each containing 7 to $12 \mu \mathrm{g}$ of DNA, were cut out of one filter.

(iii) Hybridization procedure. For fragmentation, the DNA was sheared three times in $0.1 \times$ SSC by passage through a French pressure cell at 20,000 $\mathrm{lb} / \mathrm{in}^{2}$. The denaturation of the labeled DNA was carried out by boiling the DNA $(10 \mu \mathrm{g} / \mathrm{ml}$ of $0.1 \times$ SSC) three times at $106^{\circ} \mathrm{C}$ in closed Pyrex tubes in an oil bath. The procedure for DNA-DNA hybridization followed that of McConaughy et al. (29) with slight modifications. Filters with immobilized DNA were preincubated in the mixture described by Denhardt (13) and made up with $3 \times$ SSC. After $4 \mathrm{~h}$ of incubation at the hybridization temperature, the solution was removed by aspiration and replaced by the reaction mixture, which consisted of $0.5 \mu \mathrm{g}$ of denaturated labeled DNA in $200 \mu \mathrm{l}$ of $3 \times$ SSC-formamid (50\%). Incubation was for $48 \mathrm{~h}$ at $47^{\circ} \mathrm{C}$. At the end of the incubation period, the filters were washed three times with cold $3 \times \mathrm{SSC}$, dried in a vacuum oven at $70^{\circ} \mathrm{C}$, and placed in $4 \mathrm{ml}$ of scintillation fluid $\{3 \mathrm{~g}$ of PPO [2,5-diphenyloxazole] and $250 \mathrm{mg}$ of POPOP 1,4-bis(5-phenyloxazolyl)benzene per liter of toluene $\}$. The amount of input DNA bound to the disc DNA was estimated by counting the radioactivity of the filter with a liquid scintillation counter (Packard Tricarb 4388). DNA homology values are expressed as the percentage of labeled DNA reassociated with heterologous DNA compared with that reassociated with the homologous DNA (100\%).

(iv) Determination of the $G+C$ content of the DNA. The melting temperature $\left(T_{m}\right)$ of the purified DNA was determined with a Zeiss M 4 Q III spectrophotometer by the method of Marmur and Doty (26). The $\mathrm{G}+\mathrm{C}$ content of the DNA was calculated from the equation of Mandel (26): $\mathrm{mol} \% \mathrm{G}+\mathrm{C}=2.44\left(T_{m}-\right.$ 54.6). The accuracy of the method was determined by using DNA of Micrococcus luteus DSM 20030 as a standard. The DNA G+C content of DSM 20030 $(73.5 \%)$ fell into the range published for $M$. luteus in Bergey's Manual, eighth edition.

Enzymes and radioisotopes. Acetate kinase and L-lactate dehydrogenase were purchased from Boehringer (Mannheim, Germany). Proteinase $\mathrm{K}$ was purchased from Merck. Lysozyme and ribonuclease A were obtained from Serva (Heidelberg, Germany). $\left[{ }^{3} \mathrm{H}\right]$ thymidine $(10.5 \mathrm{Ci} / \mathrm{mmol} ; 43 \mathrm{mCi} / \mathrm{mg})$ was purchased from New England Nuclear Corp.

\section{RESULTS AND DISCUSSION}

Proposal of neotype strains. With the exception of $C$. cartalyticum, type or neotype strains have not been established for the Cellulomonas species studied here. The strains used had been deposited in the ATCC in 1925 by N. R. Smith. According to R. Gordon (personal communication), it is highly likely that C. bia. zotea ATCC 486 (= DSM $20112=$ NCDO 1654 $=$ NCIB 8077), $C$. cellasea ATCC 487 (= DSM $20118=$ NCIB $8078=$ CCM 1925), $C$. fimi ATCC 484 (= DSM $20113=$ NCIB 8980), C. flavigena ATCC 482 (= DSM $20109=$ CCM $1926=$ NCIB 8073), C. gelida ATCC 488 (= DSM $20111=$ NCIB 8076), C. subalbus ATCC 489 (= DSM $20110=$ NCIB 8075), and C. uda ATCC 491 (= DSM $20107=$ NCIB 8200) are strains on which the original descriptions of the species were based. However, in the absence of definite proof linking these strains to the original descriptions, they are here proposed as the neotype strains of their respective species. Their characters conform both to those given in the original descriptions and to those of the current concept of the species with which they are associated.

Phenotypic characters. The phenotypic characters determined for the strains were as follows.

Colony morphology. On yeast extract-glucose agar, all strains formed smooth, glistening, white or yellow colonies about $5 \mathrm{~mm}$ in diameter (see Table 1).

Cell morphology. In young broth cultures, the cells were typically coryneform in appearance (Fig. 1 to 4 ) with snapping division (Vforms). After several days, most strains exhibited a more or less drastic morphological transformation into shorter rods or even coccoid cells, as described in Bergey's Manual, eighth edition. The transformation was most distinct in C. cartalyticum DSM 20106 (Fig. 1A and B), C. uda DSM 20109 (Fig. 2A and B), and Cellulomonas sp. DSM 20108 (not shown), was less pronounced in the strains of $C$. flavigena (Fig. 3A and B), C. fimi, and C. cellasea (not shown), and was almost missing in C. biazotea DSM 20112 (Fig. 4A and B). Cell morphology occasionally varied significantly between different strains of the same species, as exemplified by the two strains of $C$. fimi investigated. Many more strains of each species will have to be studied to determine whether cell morphology can be used taxonomically as a species-specific character.

Gram stain. There are conflicting opinions concerning the Gram-reaction of Cellulomonas species (19). Smears of log-phase cells of all of the strains under investigation were stained for 2.5 min with crystal violet, treated with iodine for $60 \mathrm{~s}$, and were then decolorized with $96 \%$ ethanol for $3,6,9,30,60$, or $120 \mathrm{~s}$. Afterwards the smears were stained with safranine for $15 \mathrm{~s}$. After decolorization for $9 \mathrm{~s}, 100 \%$ of the cells were gram-positive, whereas after 30,60 , and 120 $\mathrm{s}$ of decolorization, $90,0-10$, and $0 \%$ of the cells were gram-positive, respectively.

Cells of Escherichia coli K-12 and Lacobacillus plantarum DSM 20174 served as controls 


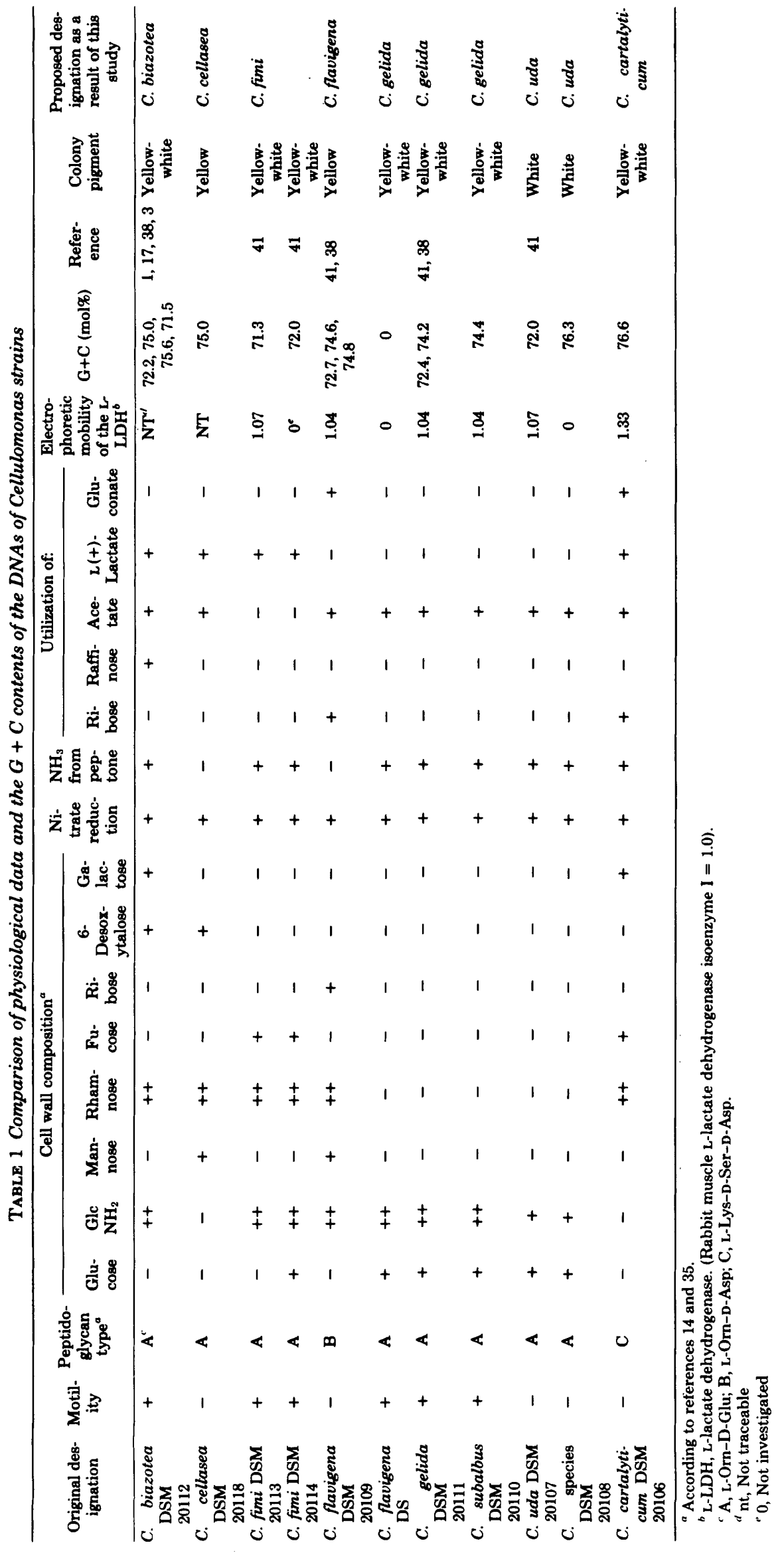




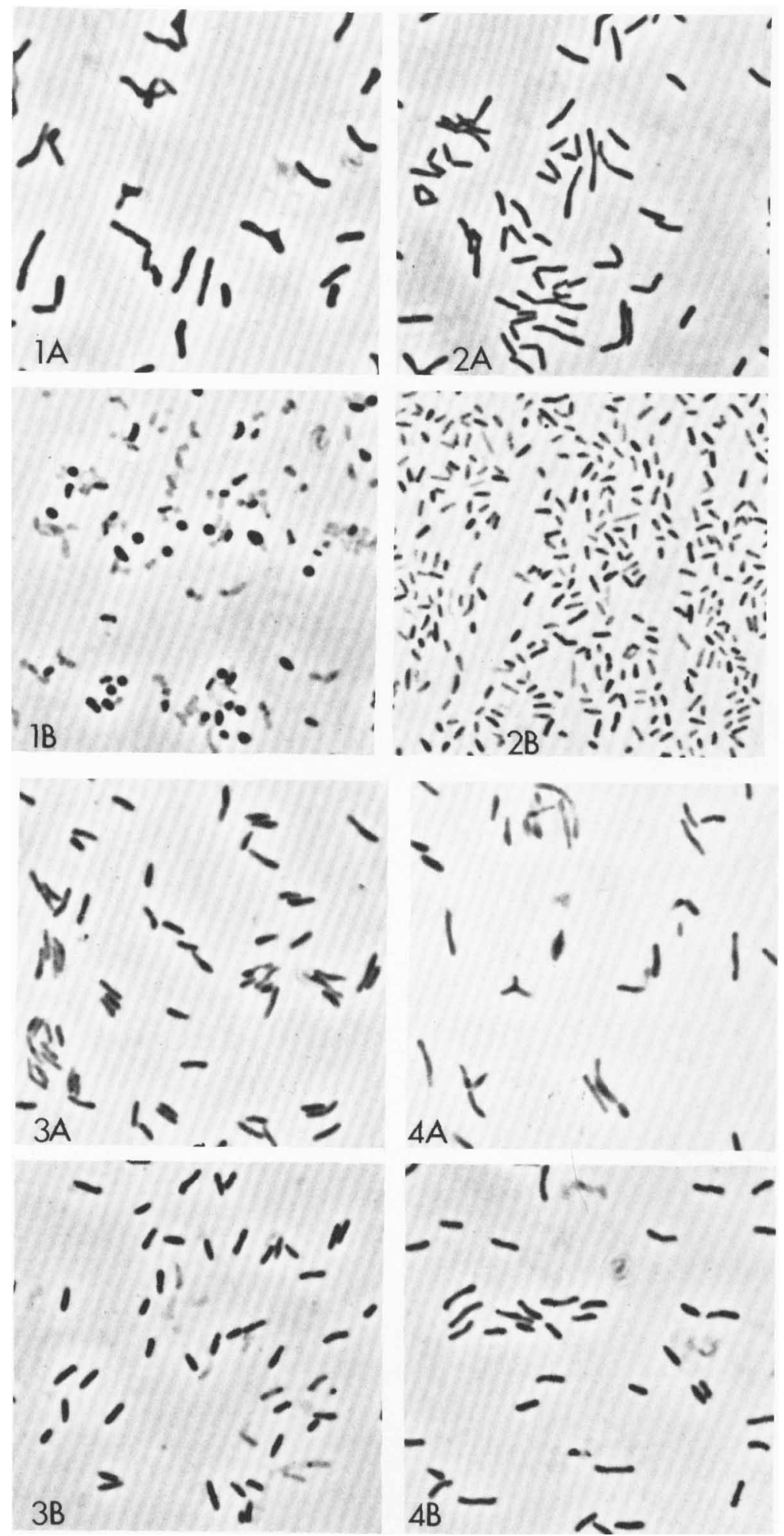

FIG. 1-4. Phase-contrast micrographs of broth cultures after 15 h (A) and 14 days (B) of incubation. Fig. 1 , C. cartalyticum; Fig. 2, C. uda; Fig. 3, C. flavigena; Fig. 4, C. biazotea. Magnification: 1,250x. 
for the Gram stain. They were gram-negative after $3 \mathrm{~s}$ or gram-positive even after $120 \mathrm{~s}$ of decolorization, respectively. The results given above demonstrated that cellulomonads are not gram-variable but are clearly gram-positive. However, the rate of decolorization is very fast, as indicated in Bergey's Manual, eighth edition. Therefore, the standard Gram stain procedure has to be modified when applied to these organisms. The fast decolorization of cells of cellulomonads is compatible with the possession of a cell wall which is much thinner than that of $L$. plantarum (unpublished data); however, cell walls of the former exhibit the chemical composition of a typical gram-positive organism (14).

Motility. Motility was observed in some of the Cellulomonas strains, and the occurrence of motility was generally in accord with that noted in the original description of these organisms $(22,23,28)$. Too few strains have been investigated, however, to permit the determination of whether motility is a strain- or species-specific characteristic. In some cases motility depended upon the medium. Cells of $C$. subalbus DSM 20110 were motile only when glucose was omitted from the medium, and C. biozatea DSM 20112 lost its motility after a few transfers when the medium was prepared with distilled water but remained motile when tap water was used.

Metabolism. In agreement with the observation by Keddie (19), all cellulomonads studied showed excellent growth under aerobic conditions and much reduced growth under anaerobic conditions. All of the strains formed acetic acid and $\mathrm{L}(+)$-lactic acid from glucose in variable amounts. Under aerobic conditions the acids were either partially or completely consumed before all of the glucose was consumed.

Acetate was utilized by all of the strains except the two strains of $C$. fimi. $\mathrm{L}(+)$-lactate was utilized by most of the strains, but it was not used by the strains of $C$. flavigena, $C$. gelida, and $C$. $u d a$ (Table 1), although it was formed by the latter strains during glucose breakdown. None of the strains utilized $\mathrm{D}(-)$-lactic acid. Although glucose can be utilized by all of the strains, gluconate, ribose, and raffinose were rarely utilized and thus may have taxonomic significance. C. biazotea DSM 20112 was the only strain which utilized raffinose, and C. flavigena DSM 20109 and $C$. cartalyticum DSM 20106 utilized ribose and gluconate, whereas all of the other strains did not. Nitrate reduction was a characteristic common to all of the strains. Ammonia was liberated from peptone by all of the strains with the exception of those of $C$. cellasea and $C$. flavigena (Table 1).

Electrophoretic mobility of L-lactate dehydrogenase. Three electrophoretically distinct types of L-lactate dehydrogenase were de- tected in the various strains (Table 1). Although the migration indexes of the L-lactate dehydrogenases of $C$. gelida DSM 20111 and $C$. flavigena DSM 20109 (1.04) and C. uda DSM 20107 and C. fimi DSM 20113 (1.07) are very similar, the two forms could be clearly differentiated by co-electrophoresis. No L-lactate dehydrogenase activity could be found after electrophoresis in the case of the strains of $C$. biazotea and $C$. cellasea, although both strains formed $\mathrm{L}(+)$-lactic acid from glucose during growth.

Cell wall composition. Three different types of peptidoglycan were found in the cell walls of the strains investigated $(14,35)$. The sugar composition of the cell wall polysaccharides also showed strain variation (Table 1).

The three peptidoglycan types are different with respect to the diamino acid of the peptide subunit, which is ornithine in all of the strains but $C$. cartalyticum DSM 20106, in which it is replaced by lysine. In most of the strains, the interpeptide bridges consist of D-glutamyl residues. However, in C. flavigena DSM 20109 a D-aspartyl residue and in C. cartalyticum DSM 20106 the dipeptide D-aspartyl-D-serine is found. The feature common to all three types is the occurrence of a dicarboxylic monoamino acid in the interpeptide bridges. The amino acid compositions of the cell walls of cellulomonads as reported by Keddie et al. (21) and Keddie and Cure (20) are in several cases not compatible with the peptidoglycan types mentioned above. Therefore, cell walls were again prepared for study from each batch of cells used for the DNADNA homology studies reported below. The peptidoglycan structure was established by determining molar ratios of the amino acids and amino sugars and by running two-dimensional paper chromatograms of the partial hydrolysates of the isolated cell walls (32). The peptidoglycan types found were the same as those reported earlier by Fiedler and Kandler (14) and are listed in Table 1 . Glycine, reported by Keddie and Cure (20) to occur in the cell walls of $C$. fimi NCIB 8980 (= DSM 20113), was not found as a component of the peptidoglycan in this species. The sugar composition of the cell wall polysaccharides is rather complex and is significantly different in most of the strains. Only the strains of C. $u d a$ and C. gelida contain only 1 neutral sugar, namely glucose.

The strains of $C$. uda and C. gelida differ from each other with respect to the cell wall content of glucosamine, however. Whereas the total hydrolysates of the cell walls of most strains, including $C$. gelida DSM 20111, contain significantly more than $1 \mathrm{~mol}$ of glucosamine per mol of muramic acid, indicating the presence of glucosamine not only in the peptidoglycan but also in an additional cell wall polymer $(14,35)$, hy- 
drolysates of C. uda DSM 20107, C. cartalyticum DSM 20106, and C. cellasea DSM 20118 contain exactly one or only slightly more than 1 mol of glucosamine. Thus, additional glucosamine residues are either missing or are present only in very small amounts.

The most common neutral cell wall sugar of the cellulomonads is rhamnose; it is present in strains of all species except C. $u d a$ and C. gelida. The other sugars occur in strains of one or two species only. Our results, except for those on $C$. biazotea DSM 20112 (= NCIB 8077), are in good accord with those published by Keddie et al. (21). Although we found that the walls of this strain contain galactose but no mannose, Keddie et al. (21) found mannose but no galactose. It remains to be determined whether the sugar composition is a significant taxonomic character at the species level or whether it varies from strain to strain, as indicated by the presence of glucose in only one of the two strains of $C$. fimi investigated. To some extent the cell wall sugar composition may also depend upon the medium. Keeping these restrictions in mind, the sugar composition may be a valuable character to distinguish species since variation in the cell wall sugars is usually rather limited.

On the basis of the phenotypic characters listed in Table 1, it seems justified in this case to distinguish seven species which differ from each other by at least six characters. The only exception is the pair $C$. gelida and $C$. uda, which differ from each other only with respect to motility, the amount of cell wall glucosamine, and the type of L-lactate dehydrogenase. However, the DNA-DNA homology between the two species is only about $50 \%$ (Table 2). Thus, these two species are more closely related to each other than they are to other species, but nevertheless their separation into two distinct species is justified. In our hands, C. flavigena DS exhibited the same physiological and biochemical characteristics as C. gelida DSM 20111 and had only a few characteristics in common with strain (DSM 20109) of $C$. flavigena. On the basis of these results, $C$. flavigena DS is here regarded as a strain of $C$. gelida.

Genetic characters. (i) $\mathbf{G}+\mathrm{C}$ content of DNA. Data on the $\mathrm{G}+\mathrm{C}$ contents of the DNAs of the known cellulomonads $(3,17,38,41)$ were supplemented by our own determinations (Table 1). The values are very similar for all strains and do not allow differentiation of species. Minor differences in the DNA G+C content ( 2 to $4 \mathrm{~mol} \%$ ) for the same species investigated by different laboratories may be due to the methods used rather than to actual differences in the strains.

The uniformity of the $\mathrm{G}+\mathrm{C}$ contents of the DNAs of the cellulomonads indicates on one hand that these organisms are closely related and on the other that they differ from other coryneforms, such as corynebacteria and arthrobacters. The $\mathrm{G}+\mathrm{C}$ contents of the DNAs of the latter are usually significantly lower (by about $10 \mathrm{~mol} \%$ ) than those of the former.

(ii) DNA-DNA homology. Labeled and unlabeled DNAs were prepared from each of the strains except C. flavigena DSM 20109 and $\mathrm{Cel}$ lulomonas sp. DSM 20108, from which only unlabeled DNA was prepared. Representatives of other coryneform genera, namely Arthrobacter, Corynebacterium, and Brevibacterium, were included in this experiment.

In the homologous system the average efficiency of renaturation in the DNA hybridization experiments was $40.4 \%$. The results of these experiments are summarized in Table 2.

Cellulomonas fimi (McBeth and Scales) Bergey et al. 1923. Both strains of $C$. fimi studied showed a high DNA homology with each other ( $91 \%$ and $103 \%$, respectively) as is to be expected for strains of the same species. All other strains yielded homology values of between 13 to $39 \%$ with $C$. fimi DNA except for the strain of $C$. biazotea, which had values of about $50 \%$. Following the opinion of Steigerwaldt et al. (36) that the lowest level of DNA homology between strains of a species should be set at $65 \%, C$. fimi and C. biazotea appear to be related but clearly distinct species. This conclusion is confirmed by the limited differences in the phenotypic characters (Table 1) of strains of the two species.

Cellulomonas biazotea (Kellermann et al.) Bergey et al. 1923. None of the Cellulomonas strains besides C. fimi DSM 20113 and DSM 20114 exhibited a higher DNA homology with $C$. biazotea DSM 20112 than $35 \%$. Thus, $C$. biazotea is unquestionably a geno-species, one that is also phenotypically distinct from other cellulomonads.

Cellulomonas gelida (Kellermann et al.) Bergey et al. 1923. C. gelida DSM 20111 is genetically identical with $C$. subalbus DSM 20110 (80 and 103\% DNA homology, respectively). The two strains are also identical with respect to their phenotypic characters. Furthermore, the original descriptions of the species (23) do not contain characters which are significantly different. Since both strains are the only available strains sent to the ATCC by N. R. Smith, one of the original authors (23), the two species names must be considered synonymous. The specific epithet gelida antedates subalbus on the basis of page priority (22), and therefore the correct name of the species formed by the union of $C$. gelida and $C$. subalbus is C. gelida. The DNA homology between $C$. gelida DSM 20111 and the strains of the other species is below $35 \%$, 


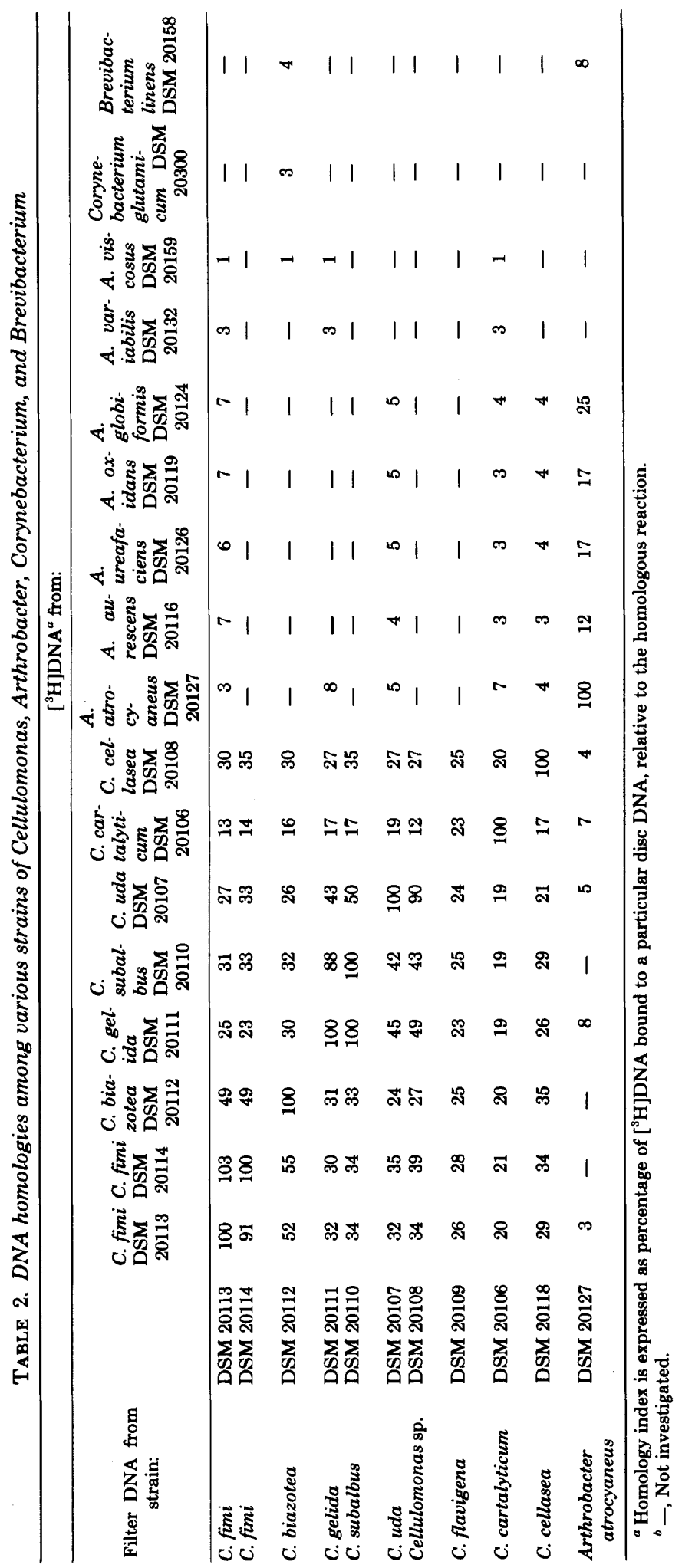


the only exception being C. uda DSM 20107, which shows a degree of homology of $50 \%$ with C. gelida. In addition, and as mentioned earlier, the phenotypic characters of $C$. gelida DSM 20111 and C. uda DSM 20107 are more nearly identical than those of the strains of any other pair of Cellulomonas species. Therefore, C. gel$i d a$ and $C$. $u d a$ are here considered to be two related, but clearly distinct, species.

Cellulomonas uda (Kellermann et al.) Bergey et al. 1923. Cellulomas sp. DSM 20108 exhibited $90 \%$ homology with the reference DNA of Cellulomas uda DSM 20207, suggesting a high degree of genetic relationship between the two. The overall relationship of the two is confirmed by the identity of their phenotypic characters. Thus, DSM 20108 is here regarded as a strain of $C$. $u d a$, as was proposed earlier by Fiedler and Kandler (14). None of the other strains tested showed a degree of homology higher than $50 \%$ with the two strains of C. $u d a$; furthermore, the phenotypic characters of the two C. $u d a$ strains are significantly different from those of the other Cellulomonas strains. Therefore, C. $u d a$ is a well-characterized and unique species, although it is related to $C$. gelida.

Cellulomonas cellasea (Kellermann et al.) Bergey et al. 1923. C. cellasea DSM 20118 showed at most $35 \%$ DNA homology with any of the other strains tested (range: 17 to $35 \%$ ) and was also phenotypically quite distinct. The species status of this organism is not questioned.

Cellulomonas flavigena (Kellermann and McBeth) Bergey et al. 1923. C. flavigena DSM 20109 showed less than 30\% DNA homology with all of the other strains tested. It also differs phenotypically by several characters from the other strains, even including a difference in the type of cell wall peptidoglycan. It is a welldefined, unique species.

Cellulomonas cartalyticum (Stackebrandt and Kandler 1979). Of the strains studied, C. cartalyticum DSM 20106 was the most distantly related to any of the other strains because its DNA homology with any other strain was not higher than $20 \%$. This finding is also compatible with the many phenotypic differences found between this strain and the others (Table 1).

The results of a numerical taxonomy study (33) have led to the proposal that $C$. cartalyticum be excluded from the genus Cellulomonas. In fact, the cell wall peptidoglycan of $C$. cartal$y$ ticum DSM 20106 is identical with that of some other non-cellulolytic coryneform organisms (35). However, the relatively high $(20 \%)$ DNA homology with all of the other Cellulomonas species, the very high $\mathrm{G}+\mathrm{C}$ content, and the cellulolytic activity argue against the exclusion of this species from Cellulomonas.

If $C$. cartalyticum DSM 20106 was a member of another genus, a DNA homology of less than $10 \%$ would be expected for this strain with the cellulomonads, for this is the value shown for $C$. cartalyticum with Arthrobacter globiformis DSM 20124, the type strain of the type species of the genus Arthrobacter.

Also A. atrocyaneus DSM 20127, although exhibiting a similar DNA G+C content to that found in cellulomonads (70\%), shares very low DNA homology with any of the Cellulomonas strains tested (4 to $8 \%$ ).

In summary, the determination of the DNA homologies between the type or proposed neotype strains of most of the named species of Cellulomonas has shown a relatively high level $(20-50 \%)$ of genetic relationship within this genus. In contrast, the DNAs of several representatives of other coryneform genera, such as $\mathrm{Ar}$. throbacter, Corynebacterium, and Brevibacterium, showed only little homology with strains of Cellulomonas. The low values of homology (4 to $8 \%$ ) obtained between cellulomonads and other coryneforms indicate merely the background of the hybridization technique, as is generally found with genetically distant organisms. Thus, Cellulomonas is a well-defined genus, one that is not different from other coryneform genera solely because of its cellulolytic activity.

The proposal by Keddie (19) to recognize only one instead of several (six) species in the genus Cellulomonas-C. flavigena-is now found to be incompatible with the many phenotypic and serological differences (4) and the moderate DNA-DNA homology between the cellulomonas.

\section{ACKNOWLEDGMENTS}

We are indebted to E. Lauer for critical remarks and helpful suggestions. We are also grateful to I. Pomper and E. Röckelein for their technical assistance.

\section{REPRINT REQUESTS}

Address reprint requests to: Dr. $O$. Kandler, Botanisches institut der Universität München, Menzinger Strasse 67, D3000 München 19, Bundesrepublik Deutschland.

\section{LTERATURE CITED}

1. Bergey, D. H., R. S. Breed, R. W. Hammer, F.-C. Harrison, and F. M. Huntoon. 1923. Bergey's manual of determinative bacteriology, 1st ed. The Williams and Wilkins Co., Baltimore.

2. Bernstiel, M. L., B. H. Sells, and I. F. Purdom. 1972. Kinetic complexity of RNA molecules. J. Mol. Biol. 63: 21-39.

3. Bousfield, I. J. 1972. A taxonomic study of some coryneform bacteria. J. Gen. Microbiol. 71:441-445.

4. Braden, A. R., and D. W. Thayer. 1976. Serological study of Cellulomonas. Int. J. Syst. Bacteriol. 26:123126.

5. Breed, R. S., E. G. D. Murray, and N. R. Smith. 1957. 
Bergey's manual of determinative bacteriology, 7th ed. The Williams and Wilkins Co., Baltimore.

6. Burton, K. 1968. Determination of DNA concentration with diphenylamine. Methods Enzymol. 12:163-166.

7. Clark, F. E. 1951. The generic classification of certain cellulolytic bacteria. Proc. Sci. Soc. Am. 15:180-182.

8. Clark, F. E. 1952. The generic classification of the soil coryneform bacteria. Int. Bull. Bacteriol. Nomencl. Taxon. 2:45-56.

9. Cowan, S. T., and K. J. Steel. 1965. Manual for the identification of medical bacteria. Cambridge University Press, Cambridge

10. Darby, K. G., A. S. Jones, J. F. Kennedy, and R. T. Walker. 1970. Isolation and analysis of the nucleic acids and polysaccharides from Clostridium welchii. $\mathrm{J}$. Bacteriol. 103:159-165.

11. Da Silva, G. A. N., and J. Holt. 1965. Numerical taxonomy of certain coryneform bacterial. J. Bacteriol. 90: 921-927.

12. Davis, G. H. G., and K. G. Newton. 1969. Numerical taxonomy of some named coryneform bacteria. J. Gen. Microbiol. 56:195-214.

13. Denhardt, D. T. 1966. A membrane-filter technique for the detection of complementary DNA. Biochem. Biophys. Res. Commun. 23:641-646.

14. Fiedler, F., and O. Kandler. 1973. Die Mureintypen in der Gattung Cellulomonas Bergey et al. Arch. Mikrobiol. 89:41-50.

15. Hohorst, H. J. 1970. L(-)-Lactat-Bestimmung mit Laktatdehydrogenase und NAD, p. 1425-1429. In Methoden der enzymatischen Analyse, Bd. 2, 2. Aufl. Weinheim/Bergstr., Verlag Chemie.

16. Holz, G., and H. U. Bergmeyer. 1970. Acetat-Bestimmung mit Acetakinase und Hydroxylamin, p. 14861490. In Methoden der enzymatischen Analyse, Bd. 2 2. Aufl. Weinheim/Bergstr., Verlag Chemie.

17. Jones, L. A., and S. G. Bradley. 1964. Phenetic classification of actinomycetes. Dev. Int. Microbiol. 5:267272.

18. Jones, D. 1975. A numerical taxonomic study of coryneform and related bacteria. J. Gen. Microbiol. 87:52-96.

19. Keddie, R. M. 1974. In: R. E. Buchanan and N. E. Gibbons (ed.), Bergey's manual of determinative bac. teriology, 8th ed., p. 629. The Williams and Wilkins Co. Baltimore.

20. Keddie, R. M., and L. Cure. 1977. The cell wall composition and distribution of free mycolic acid in named strains of coryneform bacteria and in isolates from various natural sources. J. Appl. Bacteriol. 42:229-252.

21. Keddie, R. M., B. G. S. Leask, and J. M. Grainger. 1966. A comparison of coryneform bacteria from soil and herbage: cell wall composition and nutrition. $J$. Appl. Bacteriol. 29:17-43.

22. Kellerman, F. K., and I. G. McBeth. 1912. The fermen tation of cellulose. Zentralbl. Bakteriol. Parasitenkd. Infektionskr. Hgy. Abt. 2 34:485-494.

23. Kellerman, F. K., J. G. McBeth, F. M. Scales, and N. R. Smith. 1913. Identification and classification of cellulose-dissolving bacteria. Zentralbl. Bakteriol. Parasitenkd. Infektionskr. Hyg. Abt. 2 39:502-552.
24. Mandel, M. 1962. The interaction of spermine and native deoxyribonucleic acid. J. Mol. Biol. 5:435.

25. Marmur, J. 1961. A procedure for the isolation of deoxyribonucleic acid from microorganisms. J. Mol. Biol. 3: 208-218.

26. Marmur, J., and P. Doty. 1962. Determination of the base composition of deoxyribonucleic acid from its thermal denaturation point. J. Mol. Biol. 5:109-118.

27. Maurer, H. R. 1968. Disc electrophoresis and related techniques of polyacrylamide gel electrophoresis. de Gruyter, Berlin.

28. McBeth, J. G., and F. H. Scales. 1913. The destruction of cellulose by bacteria and filamentous fungi. U.S. Bur. Plant. Ind. 266:1-52.

29. McConaughy, B. L., C. D. Laird, and B. J. McCarthy. 1969. Nucleic acid reassociation in formamide. Biochemistry 8:3289-3295.

30. Morris, J. G. 1960. Studies on the metabolism of Arthrobacter globiformis. J. Gen. Microbiol. 22:564-582.

31. Rauen, H. M. 1964. Biochemisches Taschenbuch, 2. Teil, 2. Aufl. Springer, Berlin.

32. Schleifer, K. H., and O. Kandler. 1972. Peptidoglycan types of bacterial cell walls and their taxonomic implications. Bacteriol. Rev. 36:407-477.

33. Seiler, H., G. Ohmayer, and M. Busse. 1977. Taxonomische Untersuchungen an gram positiven coryneformen Organismen unter Anwendung eines EDV-Programms zur Berechung von Vernetzungsdiagrammen. Zentralbl. Bakteriol. Parasitenkd. Infectionskr. Hyg. Abt. 1 Orig. Reihe A 238:475-488.

34. Stackebrandt, E., and O. Kandler. 1974. Biochemischtaxonomische Untersuchugen an der Gattung Cellulomonas. Zentralbl. Bakteriol. Parasitenkd. Infektionskr. Hyg. Abt. 1 Orig. Reihe A 228:128-135.

35. Stackebrandt, E., F. Fiedler, and O. Kandler. 1978. Peptidoglycan type and cell wall polysaccharide composition of Cellulomonas cartalyticum and some coryneform organisms. Arch. Microbiol. 117:115-118.

36. Steigerwaldt, A. G., G. R. Fanning, M. A. Fife-Ashbury, and D. J. Brenner. 1975. RNA relatedness among species of Enterobacter and Serratia. Can. J. Microbiol. 22:121-137.

37. Stuart, H. R., and P. E. Pease. 1972. A numerical study on the relationship of Listeria and Erysipelothrix. J. Gen. Microbiol. 73:551-565.

38. Sukapure, R. S., M. P. Lechevalier, H. Reber, M. C. Higgins, H. A. Lechevalier, and H. Prauser. 1970. Motile nocardoid Actinomycetales. Appl. Microbiol. 19: 537-543.

39. Trevelyan, W. E., D. D. Procter, and J. S. Harrison. 1950. Detection of sugars on paper chromatograms. Nature (London) 166:444-445.

40. Weber, K., and M. Osborn. 1969. The reliability of molecular weight determination by dodecyl sulfatepolyacrylamide gel electrophoresis. J. Biol. Chem. 244: 4406-4412

41. Yamada, K., and K. Komagata. 1970. Taxonomic studies on coryneform bacteria. III. DNA base composition of coryneform bacteria. J. Gen. Appl. Microbiol. 16: 215-224. 